\title{
Miniimonas arenae gen. nov., sp. nov., an actinobacterium isolated from sea sand
}

Correspondence

Harumi Ue

Harua@aol.jp

\section{Harumi Ue, ${ }^{1}$ Yoshihide Matsuo, ${ }^{2}$ Hiroaki Kasai ${ }^{3}$ and Akira Yokota $^{1}$}

\author{
${ }^{1}$ Institute of Molecular and Cellular Biosciences, The University of Tokyo, 1-1-1 Yayoi, Bunkyo-Ku, \\ Tokyo 113-0032, Japan \\ ${ }^{2}$ Suntory Holdings Limited, R\&D Planning Division, 1-1-1 Wakayamadai, Shimamoto-cho, \\ Mishima-gun, Osaka 618-8503, Japan \\ ${ }^{3}$ Marine Biosciences Kamaishi Research Laboratory, Kitasato University, 3-75-1, Heita, Kamaishi, \\ Iwate 026-0001, Japan
}

\begin{abstract}
A Gram-positive, non-motile, coccoid- to rod-shaped, non-spore-forming bacterium, designated strain $\mathrm{YM} 18-15^{\top}$, was isolated from sea sand and studied using a polyphasic taxonomic approach. Strain YM18-15 ${ }^{\top}$ grew under both aerobic and anaerobic conditions. The cell-wall peptidoglycan type was $A 4 \beta$ and ornithine was the diagnostic diamino acid. The polar lipids were phosphatidylglycerol, diphosphatidylglycerol, phosphatidylinositol and an unknown phospholipid, MK-8 $\left(\mathrm{H}_{4}\right)$ was the major menaquinone and the predominant fatty acids were anteiso- $\mathrm{C}_{15: 0}$ and $\mathrm{C}_{16: 0}$. The DNA G+C content was 74.2 mol\%. High 16S rRNA gene sequence similarities (96.3-97.3\%) were found with the sequences of the type strains of the three genera of the family Beutenbergiaceae. Phylogenetic analysis based on 16S rRNA gene sequences showed that strain YM18-15 ${ }^{\top}$ formed a clade with Serinibacter salmoneus, Salana multivorans and Beutenbergia cavernae. Strain YM18-15 ${ }^{\top}$ differed from these three type strains in chemotaxonomic characteristics and in 16S rRNA gene signature nucleotides. Based on genetic and chemotaxonomic evidence, it is suggested that strain $\mathrm{YM} 18-15^{\top}$ represents a novel species of a new genus within the family Beutenbergiaceae, for which the name Miniimonas arenae gen. nov., sp. nov. is proposed. The type strain of the type species is YM18-15 ${ }^{\top}$ (=NBRC $106267^{\top}=$ KCTC $19750^{\top}=$ MBIC $08348^{\top}$ ).
\end{abstract}

The family Beutenbergiaceae within the suborder Micrococcineae was proposed by Zhi et al. (2009). The family Beutenbergiaceae contains three genera, Salana (von Wintzingerode et al., 2001), Beutenbergia (Groth et al., 1999) and Serinibacter (Hamada et al., 2009). Each of these genera is represented by only one species. Salana multivorans DSM $13521^{\mathrm{T}}$ was isolated from an anaerobic bioreactor, Beutenbergia cavernae DSM $12333^{\mathrm{T}}$ was isolated from a cave and Serinibacter salmoneus DSM $21801^{\mathrm{T}}$ was isolated from the intestinal tract of a fish. In the present study, we describe a bacterium, strain YM18-15 ${ }^{\mathrm{T}}$, which was isolated from sea sand in Teguma fishing harbour in Nagasaki Prefecture, Japan. It is proposed that strain YM18-15 ${ }^{\mathrm{T}}$ represents a novel species in a new genus within the family Beutenbergiaceae.

Isolation was performed on $\mathrm{H}$ medium (for composition, see Supplementary Method in IJSEM Online) at $25{ }^{\circ} \mathrm{C}$ for 30 days. Strain $\mathrm{YM} 18-15^{\mathrm{T}}$ was maintained as glycerol

The GenBank/EMBL/DDBJ accession number for the $16 \mathrm{~S}$ rRNA gene sequence of strain YM18-15 ${ }^{\top}$ is AB522642.

Supplementary material is available with the online version of this paper. suspensions $(20 \%, \mathrm{v} / \mathrm{v})$ at $-80{ }^{\circ} \mathrm{C}$. Biomass for phenotypic tests was obtained from Luria-Bertani (LB) broth (Difco) by incubating at $30{ }^{\circ} \mathrm{C}$ for 1 week. Biomass for chemical and molecular systematic studies was obtained by culturing the strain in IL8 medium (10 g lactose, $10 \mathrm{~g}$ polypeptone, $15 \mathrm{~g}$ yeast extract, $10 \mathrm{~g} \mathrm{NaCl}$ ), except for the cells used for the preparation of fatty acids. For quantitative analysis of whole-cell fatty acids, cells were grown on tryptic soy agar (TSA) at $30{ }^{\circ} \mathrm{C}$ for 7 days. Gram staining and tests for motility were performed with the Favor G (Nissui) and API M media (bioMérieux), respectively, according to the manufacturers' instructions.

Morphology was observed using light microscopy (ECLIPSE E600; Nikon). Colony morphology and colour were observed on LB agar (Difco) at $30{ }^{\circ} \mathrm{C}$ for 1 week. Growth was tested at 5, 10, 15, 20, 25, 28, 35, 37, 42, 45 and $50{ }^{\circ} \mathrm{C}$ on $\mathrm{LB}$ agar. Experiments investigating tolerance to $\mathrm{NaCl}$ were carried out using LB broth as the basal medium. The following $\mathrm{NaCl}$ concentrations $(\mathrm{w} / \mathrm{v})$ were tested: 0.5 , $2,5,8,10,15$ and $20 \%$. For determination of the optimal $\mathrm{pH}$ for growth, cells were grown on LB agar at $\mathrm{pH} 5-11$ at $30{ }^{\circ} \mathrm{C}$ for 3 weeks. The ability of the novel strain to use sole 
carbon sources was tested with International Streptomyces Project (ISP) medium 9 (Difco) supplemented with $1 \%$ $(\mathrm{w} / \mathrm{v})$ carbon source for 3 weeks. The activity of several enzymes was determined by using API ZYM (bioMérieux) and checked after $24 \mathrm{~h}$. Several physiological tests were performed using the API 20NE kit (bioMérieux). Acid production under anaerobic conditions was assayed using API 20A (bioMérieux). API tests were performed twice. The oxidase reaction was tested by using cytochrome oxidase test paper (Nissui Pharmaceutical Co.). Catalase activity was determined based on production of bubbles after the addition of a drop of $3 \% \mathrm{H}_{2} \mathrm{O}_{2}$. All phenotypic assays (except analysis of the temperature range) were carried out at $30{ }^{\circ} \mathrm{C}$, which was in the range of optimal growth temperatures for the strain.

Menaquinones were extracted using the procedures described by Collins et al. (1977) and analysed by LCMS as described by Ogiso et al. (2008), but without adding phosphoric acid to the elution buffer. Polar lipids were extracted according to Minnikin et al. (1984) and analysed by TLC. The purified cell wall was obtained by using the method described by Schleifer \& Kandler (1972). Amino acids in cell-wall hydrolysates were analysed by twodimensional ascending TLC on cellulose plates (Merck) by using the solvent systems of Harper \& Davis (1979) and by HPLC as their phenylthiocarbamoyl derivatives with a Wakopak WS-PTC column (Wako Pure Chemical Industries) (Yokota et al., 1993). Analysis of the wholecell fatty acid pattern was performed by using the MIDI system (Microbial ID, Inc.). Mycolic acids were analysed by the method of Minnikin et al. (1975). The acyl type of the muramic acid in the cell wall was determined according to the method described by Uchida et al. (1999). Analysis of sugars from whole-cell hydrolysates was performed using the procedures described by Staneck \& Roberts (1974). DNA was prepared according to the method of Suzuki et al. (1999). The DNA base composition of strain YM18$15^{\mathrm{T}}$ was determined by reversed-phase HPLC using a DNA-GC kit (Yamasa) according to the method of Kumagai et al. (1988).

An approximately $1500 \mathrm{bp}$ fragment of the 16S rRNA gene was amplified from the extracted DNA by using bacterial universal primers 27F and 1492R (Escherichia coli numbering system; Weisburg et al., 1991) specific to the 16S rRNA gene. A sequence similarity search was conducted using GenBank BLASTN (National Center for Biotechnology Information). Sequences of closely related taxa were retrieved and aligned using the CLUSTAL_X program (Thompson et al., 1997) and the alignment was corrected manually. Aligned sequences were analysed by using MEGA 4.0.2 software (Tamura et al., 2007). For neighbour-joining analysis (Saitou \& Nei, 1987), genetic distances were calculated using Kimura's two-parameter model (Kimura, 1983). Clustering with the neighbour-joining (Saitou \& Nei, 1987) and maximum-parsimony (Fitch, 1971) methods was determined by using bootstrap values based on
1000 replications (Felsenstein, 1985). Similarity values were calculated using the MEGA software.

The components of the peptidoglycan of strain YM18-15 were Ala, Ser, Glu and Orn in a molar ratio of $0.4: 0.5: 1.0: 0.4$ and the peptidoglycan type was $A 4 \beta$ (Schleifer \& Kandler, 1972) with an interpeptide bridge of Orn-Glu. The fatty acid pattern was of the iso- and anteisobranched and straight-chain saturated type. Major fatty acids were anteiso- $\mathrm{C}_{15: 0}(46.7 \%)$ and $\mathrm{C}_{16: 0}(23.2 \%)$ and minor fatty acids were anteiso- $\mathrm{C}_{17: 0}(9.4 \%), \mathrm{C}_{14: 0}(5.4 \%)$, iso- $\mathrm{C}_{16: 0}(3.8 \%)$, iso- $\mathrm{C}_{15: 0}(3.4 \%)$, iso- $\mathrm{C}_{14: 0}(2.8 \%), \mathrm{C}_{15: 0}$ $(2.3 \%)$ and iso- $\mathrm{C}_{17: 0}(1.5 \%)$. The detailed fatty acid composition of strain YM18- $15^{\mathrm{T}}$ is given in Supplementary Table S1 (see IJSEM Online). The isoprenoid quinones were menaquinones of type MK- $8\left(\mathrm{H}_{4}\right)(88.5 \%)$, MK-8 (7.0\%), MK-8 $\left(\mathrm{H}_{2}\right)(2.7 \%)$ and MK-8 $\left(\mathrm{H}_{6}\right)(1.8 \%)$. The polar lipids consisted of phosphatidylinositol, phosphatidylglycerol, diphosphatidylglycerol and an unknown phospholipid. The DNA G +C content was $74.2 \mathrm{~mol} \%$.

Phylogenetic analysis based on the neighbour-joining method showed that strain YM18- $15^{\mathrm{T}}$ was positioned within the family Beutenbergiaceae of the suborder Micrococcineae and joined the phylogenetic lineage of Serinibacter salmoneus DSM $21801^{\mathrm{T}}$ (Fig. 1). The relative position of strain $\mathrm{YM} 18-15^{\mathrm{T}}$ was also confirmed in the maximum-parsimony tree. The BLAST sequence similarity result based on the 16S rRNA gene sequence revealed that strain $\mathrm{YM} 18-15^{\mathrm{T}}$ was closely related to Serinibacter salmoneus DSM $21801^{\mathrm{T}}$ (sequence similarity 97.3\%), Salana multivorans DSM $13521^{\mathrm{T}}(96.3 \%)$ and B. cavernae DSM $12333^{\mathrm{T}}(97.1 \%)$ of the family Beutenbergiaceae.

The differences in cell morphology and chemotaxonomic characteristics between strain YM18-15 ${ }^{\mathrm{T}}$ and members of the genera Serinibacter, Salana and Beutenbergia are shown in Table 1. The most noticeable differences were in the polar lipids. The peptidoglycan type of the cell wall was $A 4 \beta$ (containing Orn) for strain YM18-15 ${ }^{\mathrm{T}}$, but A4 $\alpha$ (containing Lys) for the genera Serinibacter and Beutenbergia. The combination of major fatty acids (anteiso- $\mathrm{C}_{15: 0}$ and $\mathrm{C}_{16: 0}$ ) for strain YM18- $15^{\mathrm{T}}$ did not match those of the genera Salana or Beutenbergia. The results of detailed test reactions are presented in the species description and Supplementary Table S2 (available in IJSEM Online). The pattern of the $16 \mathrm{~S}$ rRNA gene sequence signature nucleotides is shown in Supplementary Table S3. The pattern of $16 \mathrm{~S}$ rRNA signature nucleotides consisted of nucleotides at positions 140:223 (G-C), 589:650 (U-A), 610 (U), 612:628 (C-G), 616:624 $(\mathrm{G}-\mathrm{C}), 839: 847(\mathrm{C}-\mathrm{A})$ and $863(\mathrm{~A})$, which indicated that strain $\mathrm{YM} 18-15^{\mathrm{T}}$ did not belong to any recognized genus within the family Beutenbergiaceae, having signature nucleotide differences from Serinibacter salmoneus DSM $21801^{\mathrm{T}}$ (three positions), Salana multivorans DSM $13521^{\mathrm{T}}$ (three positions) and B. cavernae DSM $12333^{\mathrm{T}}$ (four positions). The pattern of 16S rRNA gene signature nucleotides of strain YM18- $15^{\mathrm{T}}$ perfectly matched that given in the description of the family Beutenbergiaceae as reported by Hamada et al. 


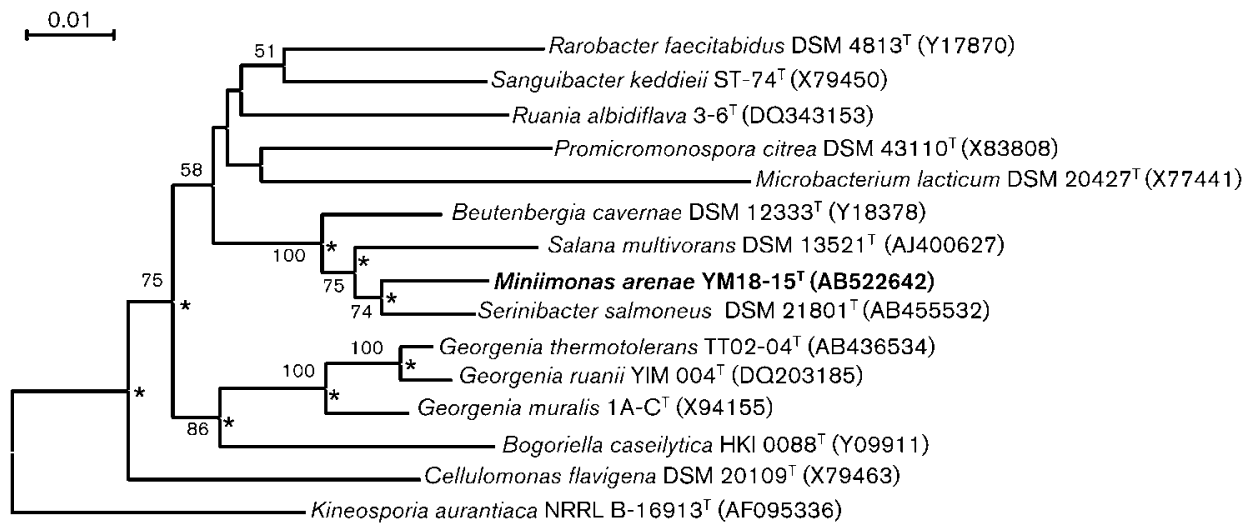

Fig. 1. Neighbour-joining phylogenetic tree, based on $16 \mathrm{~S}$ rRNA gene sequences (1368 bases), for strain $\mathrm{YM}^{\mathrm{N}} \mathrm{18}-15^{\top}$, all the members of the family Beutenbergiaceae and type strains from related genera within the suborder Micrococcineae. Only values with $>50 \%$ significance are shown. Asterisks indicate that the corresponding nodes were also recovered in the maximumparsimony tree. Kineosporia aurantiaca NRRL B-16913 ${ }^{\top}$ was used as an outgroup. Bar, $0.01 K_{\text {nuc }}$.

(2009). Strain YM18-15 ${ }^{\mathrm{T}}$ and the genera Beutenbergia, Salana and Serinibacter had an A-G at position 131:231, not a $C-G$ as reported by Zhi et al. (2009). From the differences in its chemotaxonomic and genotypic properties, strain YM18- $15^{\mathrm{T}}$ is considered to represent a novel genus of the family Beutenbergiaceae, for which the name Miniimonas arenae gen. nov., sp. nov. is proposed.

\section{Description of Miniimonas gen. nov.}

Miniimonas (Mi.ni.i.mo' nas. L. adj. minius cinnabar-red, vermilion; L. fem. n. monas a unit, monad; N.L. fem. $\mathrm{n}$. Miniimonas vermilion monad, referring to the colour of the cell mass).

Gram-positive, non-motile, coccoid- to rod-shaped, oxidasenegative and catalase-positive. Growth occurs under both aerobic and anaerobic conditions (i.e. facultatively anaerobic). The major menaquinone is MK- $8\left(\mathrm{H}_{4}\right)$. The fatty acid pattern is of the iso- and anteiso-branched and straight-chain saturated type. The major fatty acids are anteiso- $\mathrm{C}_{15: 0}$ and $\mathrm{C}_{16: 0}$. The cell-wall peptidoglycan contains Orn, Ser, Ala and Glu. The whole-cell sugars are galactose, xylose and ribose. Mycolic acids are absent. The acyl type of muramic acid is acetyl. The polar lipids are phosphatidylglycerol, diphosphatidylglycerol, phosphatidylinositol and one unknown phospholipid. Phylogenetically, the genus Miniimonas belongs to the family Beutenbergiaceae of the suborder Micrococcineae of the class Actinobacteria. The type species is Miniimonas arenae.

\section{Description of Miniimonas arenae sp. nov.}

Miniimonas arenae (a.re'na.e. L. gen. n. arenae of sand, isolated from sea sand).

Displays the following properties in addition to those given in the genus description. Rod-shaped cells are $0.6-3.7 \mu \mathrm{m}$ in length. Cells exhibit a rod-coccus cycle. The diameters of

Table 1. Cell morphology and differential chemotaxonomic characteristics of strain $\mathrm{YM} 18-15^{\top}$ and type strains of the genera Serinibacter, Salana and Beutenbergia

Taxa: 1, YM18-15 ${ }^{\mathrm{T}}$; 2, Serinibacter salmoneus DSM $21801^{\mathrm{T}}$ (data from Hamada et al., 2009); 3, Salana multivorans DSM $13521^{\mathrm{T}}$ (von Wintzingerode et al., 2001); 4, Beutenbergia cavernae DSM $12333^{\mathrm{T}}$ (Groth et al., 1999). The major menaquinone was $\mathrm{MK}-8\left(\mathrm{H}_{4}\right)$ for all taxa. PG, Phosphatidylglycerol; DPG, diphosphatidylglycerol; PI, phosphatidylinositol; PE, phosphatidylethanolamine; PL(s), unknown phospholipid(s).

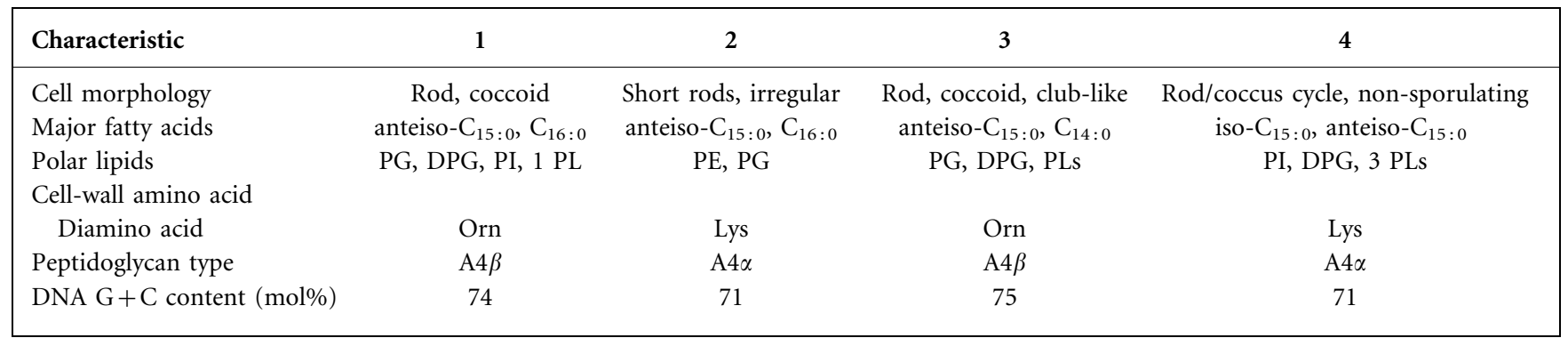


the cocci are $1.0-1.7 \mu \mathrm{m}$. Growth occurs weakly at 25$30{ }^{\circ} \mathrm{C}$. The $\mathrm{pH}$ range for growth is $5-11$, with optimum growth at $\mathrm{pH} 7-7.5$. Cells grow in the absence of $\mathrm{NaCl}$, but tolerate up to $5 \% \mathrm{NaCl}(\mathrm{w} / \mathrm{v})$. When grown aerobically for 7 days on LB agar or IL8 medium agar, the type strain forms a vermilion-coloured cell mass. Does not form spores. Cells form circular and smooth colonies that are $1-4 \mathrm{~mm}$ diameter after 7 days at $30{ }^{\circ} \mathrm{C}$ on $\mathrm{LB}$ agar. Nitrate is reduced to nitrite. $\mathrm{H}_{2} \mathrm{~S}$ is not produced. Hydrolysis of starch is negative. The type strain forms vermilion-coloured colonies. Based on API ZYM tests, cells are positive for esterase lipase (C8), leucine arylamidase, naphthol AS-BI-phosphohydrolase, $\alpha$-galactosidase, $\beta$-galactosidase, $\alpha$-glucosidase and $\beta$-glucosidase, but negative for alkaline phosphatase, lipase (C14), valine arylamidase, cystine arylamidase, trypsin, chymotrypsin, $\beta$-glucuronidase, $N$-acetyl- $\beta$-glucosaminidase, $\alpha$-mannosidase and $\alpha$-fucosidase. Cells are weakly positive for esterase (C4) and acid phosphatase. Utilizes the following substrates as sole carbon sources: L-arabinose, D-mannose, D-xylose, D-glucose, D-fructose, L-rhamnose and maltose monohydrate, but does not utilize D-mannitol. Anaerobic formation of acid from API $20 \mathrm{~A}$ is positive for glucose, sucrose, maltose, D-xylose, L-arabinose, D-mannose, raffinose, L-rhamnose and trehalose, weakly positive for cellobiose and negative for D-mannitol, lactose, salicin, glycerol, melezitose and D-sorbitol. Based on API 20A tests, cells are anaerobically positive for the hydrolysis of aesculin, but negative for the hydrolysis of gelatin and for the production of indole, arginine dihydrolase and urease. The peptidoglycan type, polar lipids, fatty acid pattern and major menaquinone are as given in the genus description.

The type strain, YM18- $15^{\mathrm{T}}\left(=\mathrm{NBRC} 106267^{\mathrm{T}}=\mathrm{KCTC}\right.$ $19750^{\mathrm{T}}=$ MBIC $08348^{\mathrm{T}}$ ), was isolated from sea sand in Teguma fishing harbour in Nagasaki Prefecture, Japan. The $\mathrm{G}+\mathrm{C}$ content of the genomic DNA is $74.2 \mathrm{~mol} \%$.

\section{Emended description of the family Beutenbergiaceae Zhi et al. 2009 emend. Hamada et al. 2009}

The description of the family is as emended by Hamada et al. (2009), but the 16S rRNA gene sequence signature nucleotide pattern contains an A-G at position $131: 231$, not a C-G (Zhi et al., 2009). The family contains the type genus Beutenbergia (Groth et al., 1999), as well as the genera Salana (von Wintzingerode et al., 2001), Serinibacter (Hamada et al., 2009) and Miniimonas.

\section{Acknowledgements}

We would like to thank Atsuko Katsuta for technical assistance with isolation and preservation of the strain and Dr Ritsuko Katahira for LCMS analysis of quinones. We are grateful to Dr J. P. Euzéby (Ecole Nationale Vétérinaire, Toulouse, France) for his support with nomenclatural problems. This work was supported in part by a research grant (2009-2011) from the Institute for Fermentation, Osaka, Japan.

\section{References}

Collins, M. D., Pirouz, T., Goodfellow, M. \& Minnikin, D. E. (1977). Distributions of menaquinones in actinomycetes and corynebacteria. J Gen Microbiol 100, 221-230.

Felsenstein, J. (1985). Confidence limits on phylogenies: an approach using the bootstrap. Evolution 39, 783-791.

Fitch, W. M. (1971). Toward defining the course of evolution: minimum change for a specific tree topology. Syst Zool 20, 406416.

Groth, I., Schumann, P., Schuetze, B., Augsten, K., Kramer, I. \& Stackebrandt, E. (1999). Beutenbergia cavernae gen. nov., sp. nov., an L-lysine-containing actinomycete isolated from a cave. Int $J$ Syst Bacteriol 49, 1733-1740.

Hamada, M., lino, T., Tamura, T., Iwami, T., Harayama, S. \& Suzuki, K. (2009). Serinibacter salmoneus gen. nov., sp. nov., an actinobacterium isolated from the intestinal tract of a fish, and emended descriptions of the families Beutenbergiaceae and Bogoriellaceae. Int J Syst Evol Microbiol 59, 2809-2814.

Harper, J. J. \& Davis, G. H. G. (1979). Two-dimensional thin-layer chromatography for amino acid analysis of bacterial cell walls. Int $J$ Syst Bacteriol 29, 56-58.

Kimura, M. (1983). The Neutral Theory of Molecular Evolution. Cambridge: Cambridge University Press.

Kumagai, M., Fujimoto, M. \& Kuninaka, A. (1988). Determination of base composition of DNA by high performance liquid chromatography of its nuclease P1 hydrolysate. Nucleic Acids Symp Ser 19, 6568.

Minnikin, D. E., Alshamaony, L. \& Goodfellow, M. (1975). Differentiation of Mycobacterium, Nocardia, and related taxa by thin layer chromatographic analysis of whole-cell methanolysates. J Gen Microbiol 88, 200-204.

Minnikin, D. E., O’Donnell, A. G., Goodfellow, M., Alderson, G., Athalye, M., Schaal, A. \& Parlett, J. H. (1984). An integrated procedure for the extraction of bacterial isoprenoid quinones and polar lipids. J Microbiol Methods 2, 233-241.

Ogiso, H., Suzuki, T. \& Taguchi, R. (2008). Development of a reversephase liquid chromatography electrospray ionization mass spectrometry method for lipidomics, improving detection of phosphatidic acid and phosphatidylserine. Anal Biochem 375, 124-131.

Saitou, N. \& Nei, M. (1987). The neighbor-joining method: a new method for reconstructing phylogenetic trees. Mol Biol Evol 4, 406425.

Schleifer, K. H. \& Kandler, O. (1972). Peptidoglycan types of bacterial cell walls and their taxonomic implications. Bacteriol Rev 36, 407477.

Staneck, J. L. \& Roberts, G. D. (1974). Simplified approach to identification of aerobic actinomycetes by thin-layer chromatography. Appl Microbiol 28, 226-231.

Suzuki, M., Nakagawa, Y., Harayama, S. \& Yamamoto, S. (1999). Phylogenetic analysis of genus Marinilabilia and related bacteria based on the amino acid sequences of GyrB and emended description of Marinilabilia salmonicolor with Marinilabilia agarovorans as its subjective synonym. Int J Syst Bacteriol 49, 1551-1557.

Tamura, K., Dudley, J., Nei, M. \& Kumar, S. (2007). MEGA4: Molecular evolutionary genetics analysis (MEGA) software version 4.0. Mol Biol Evol 24, 1596-1599. 
Thompson, J. D., Gibson, T. J., Plewniak, F., Jeanmougin, F. \& Higgins, D. G. (1997). The CLUSTAL_X windows interface: flexible strategies for multiple sequence alignment aided by quality analysis tools. Nucleic Acids Res 25, 4876-4882.

Uchida, K., Kudo, T., Suzuki, K. \& Nakase, T. (1999). A new rapid method of glycolate test by diethyl ether extraction, which is applicable to a small amount of bacterial cells of less than one milligram. J Gen Appl Microbiol 45, 49-56.

von Wintzingerode, F., Göbel, U. B., Siddiqui, R. A., Rösick, U., Schumann, P., Frühling, A., Rohde, M., Pukall, R. \& Stackebrandt, E. (2001). Salana multivorans gen. nov., sp. nov., a novel actinobacterium isolated from an anaerobic bioreactor and capable of selenate reduction. Int J Syst Evol Microbiol 51, 1653-1661.
Weisburg, W. G., Barns, S. M., Pelletier, D. A. \& Lane, D. J. (1991). $16 \mathrm{~S}$ ribosomal DNA amplification for phylogenetic study. J Bacteriol 173, 697-703.

Yokota, A., Tamura, T., Nishii, T. \& Hasegawa, T. (1993). Kineococcus aurantiacus gen. nov., sp. nov., a new aerobic, gram-positive, motile coccus with meso-diaminopimelic acid and arabinogalactan in the cell wall. Int J Syst Bacteriol 43, 52-57.

Zhi, X.-Y., Li, W.-J. \& Stackebrandt, E. (2009). An update of the structure and 16S rRNA gene sequence-based definition of higher ranks of the class Actinobacteria, with the proposal of two new suborders and four new families and emended descriptions of the existing higher taxa. Int J Syst Evol Microbiol 59, 589-608. 